\title{
Modelling homeostatic control of high-frequency post-synaptic transmission and its effect on metabolic efficiency in the auditory brainstem
}

Yann Sweeney ${ }^{1,2^{*}}$, Jeanette Hellgren-Kotaleski ${ }^{2}$, Matthias Hennig ${ }^{1}$

From Twenty Second Annual Computational Neuroscience Meeting: CNS*2013

Paris, France. 13-18 July 2013

Intrinsic electrical properties of neurons are controlled by a number of homeostatic mechanisms, among which is the modulation of conductances of voltage-dependent ion channels. One such example is mediated by Nitric Oxide (NO) in principal neurons of the Medial Nucleus of the Trapezoid Body (MNTB) in the auditory brainstem. These act as relay neurons, receiving excitatory input and transmitting inhibitory signals to the auditory nuclei involved in sound localisation. NO is released here in an activitydependent manner and switches the basis of action potential (AP) repolarisation from $\mathrm{K}_{\mathrm{v}} 3$ to $\mathrm{K}_{\mathrm{v}} 2$, decreasing intrinsic excitability and improving faithful following of
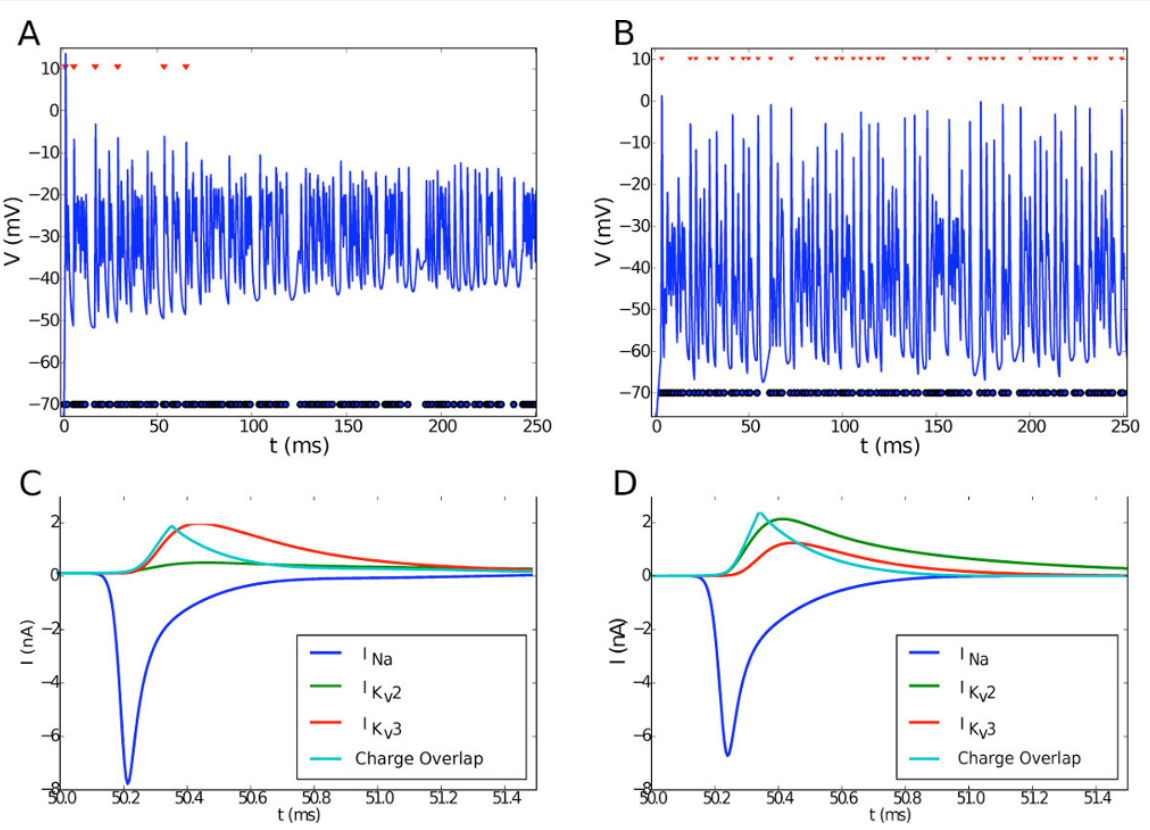

Figure 1 The NO-mediated conductance state (B) improves transmission ratios at $800 \mathrm{~Hz}$ compared to the naïve state (A). Blue circles represent Poisson synaptic input and red triangles represent a successfully evoked AP. The lower panels show the Nav, $K_{v} 2$ and $K_{v} 3$ currents during an AP, with the charge overlap in cyan. The area under the cyan curve is used as a measure of AP metabolic efficiency [3] and is higher in the NO-mediated case (D) compared to the naïve (C), thus rendering it less efficient.

\footnotetext{
* Correspondence: yann.sweeney@ed.ac.uk

'IANC, School of Informatics, University of Edinburgh, UK

Full list of author information is available at the end of the article
} 
high frequency input trains [1]. We have replicated these effects in a biophysically detailed neuron model and have measured both transmission fidelity and metabolic efficiency of AP generation, quantified by the $\mathrm{Na}^{+} / \mathrm{K}^{+}$charge overlap ratio [3], across varying states of $\mathrm{NO}$ activation.

It is observed that increasing $\mathrm{K}_{\mathrm{v}} 2$ conductance leads to improved post-synaptic transmission at high frequencies, while also decreasing the metabolic efficiency of an action potential. The location of $\mathrm{K}_{\mathrm{v}} 2$ channels adjacent to $\mathrm{Na}_{\mathrm{v}}$ channels at the axon initial segment (AIS), as opposed to $\mathrm{K}_{\mathrm{v}} 3$, which is located at the soma, is found to be crucial in determining how it affects metabolic efficiency. Figure 1 illustrates that NO mediates transition between a metabolically efficient state sufficient to perform its function at low activity and a metabolically inefficient state required in order to sustain transmission fidelity at high frequencies. This finding provides a plausible justification for the presence of an activity-dependent switch of dominant potassium channel in the MNTB. This effect has subsequently been observed in a CA3 pyramidal cell model [3], a more generic neuron morphology in which $\mathrm{NO}$ is also known to act on $\mathrm{K}_{\mathrm{v}}$ conductances [1].

\section{Acknowledgements}

This work was supported by the Erasmus Mundus EuroSPIN programme (YS) and MRC Fellowship G0900425 (MHH).

\section{Author details}

'IANC, School of Informatics, University of Edinburgh, UK. ${ }^{2}$ Department of

Computational Biology, KTH, Stockholm, Sweden.

Published: 8 July 2013

\section{References}

1. Steinert JR, Robinson SW, Tong MD, Haustein ID: Nitric oxide is an activitydependent regulator of target neuron intrinsic excitability. Neuron 2011, 71(2):291-305.

2. Hallermann S, de Kock CPJ, Stuart GJ, Kole MHP: State and location dependence of action potential metabolic cost in cortical pyramidal neurons. Nat Neurosci 2012, 15(7):1007-1014.

3. Traub R, Wong R, Miles R, Michelson H: A model of a CA3 hippocampal pyramidal neuron incorporating voltage-clamp data on intrinsic conductances. J Neurol Neurophysiol 1991, 66:635-50.

doi:10.1186/1471-2202-14-S1-P167

Cite this article as: Sweeney et al:: Modelling homeostatic control of high-frequency post-synaptic transmission and its effect on metabolic efficiency in the auditory brainstem. BMC Neuroscience 2013 14(Suppl 1): P167.

\section{Submit your next manuscript to BioMed Central} and take full advantage of:

- Convenient online submission

- Thorough peer review

- No space constraints or color figure charges

- Immediate publication on acceptance

- Inclusion in PubMed, CAS, Scopus and Google Scholar

- Research which is freely available for redistribution

Submit your manuscript at www.biomedcentral.com/submit 